\title{
Immunodiagnostic Applications of Polyclonal Antibodies that Recognize the Southern Bean Mosaic Virus Movement Protein
}

\author{
Fernanda Serrano Romano ${ }^{1}$, Angela Rocio Nino Santisteban ${ }^{1}$, Carolina Gismene ${ }^{1}$, Liege Abdallah \\ Kawai $^{1}$, Raghuvir Krishnaswamy Arni*1,2 and Ricardo Mariutti*1 \\ ${ }^{1}$ Multiuser Center for Biomolecular Innovation, Brazil \\ ${ }^{2}$ Department of Physics, Brazil
}

*Corresponding author: Raghuvir Krishnaswamy Arni, Multiuser Center for Biomolecular Innovation, Brazil

Ricardo Mariutti, Department of Physics, Brazil

\section{ARTICLE INFO}

Received: 蔧 February 20, 2019

Published: February 27, 2019

Citation: Fernanda Serrano R, Angela Rocio Nino S, Carolina G, Liege Abdallah K, Raghuvir Krishnaswamy A, Ricardo M. Immunodiagnostic Applications of Polyclonal Antibodies that Recognize the Southern Bean Mosaic Virus Movement Protein. Biomed J Sci \& Tech Res 15(2)-2019. BJSTR. MS.ID.002678.
ABSTRACT

Southern Bean Mosaic Virus (SBMV) invades plant adjacent cells through the interconnections of plasmodesmata channels, using Movement Proteins (MPs), usually produced in low concentrations, that are able to dilate the plasmodesmata enabling the passage of complexes formed by viral nucleic acids and proteins or even of whole virions. This virus has a strict host range and some of them infect the common bean and soya, which are of economic relevance. Therefore, the production of antibodies for the efficient detection of even low concentrations of MPs from SBMV which belongs to the Sobemovirus genus is important. The polyclonal antibody obtained was able to react specifically with the MP from SBMV both under denaturing and native conditions and served to determine via immunoblotting assays the MP concentration in infected bean leaves.

Keywords: Southern Bean Mosaic Virus; Polyclonal Antibodies; Movement Protein; Circular Dichroism Spectroscopy; Western Blot; Immunoblotting

\section{Introduction}

Plant viruses invade and spread through their hosts either via the short-distance movement which involves the spreading of the virus from the infected cell to the adjacent cell, or, via the long-distance movement where the virus spreads through the vascular system and infects cells from different regions of the plant. In the first case, viruses penetrate the cell wall through the plasmodesmata, which are channels unique in the plant kingdom, typically with diameters of about 25-30 $\mathrm{nm}$, that interconnect cells [1-3]. Different species of plant viruses encode specialized proteins referred to as Movement Proteins (MPs) that dilate the plasmodesmata permitting the passage of complexes formed by viral nucleic acids and proteins or even of whole virions [4].

There is no common movement mechanism that is shared by all viruses and viruses, independent of their taxonomy, may resort to different strategies depending on the MP sequence, participation of virus encoded proteins, type of infected host and interaction with host factors [5-7]. MPs, as well as replicases are non-structural proteins that are generally produced in very low concentration in plants thus making it difficult to identify, localize and purify them [8].

The aim of this study is the production of antibodies for the efficient detection of low concentrations of MPs from the Southern Bean Mosaic Virus (SBMV) which belongs to the Sobemovirus genus. This virus has a strict host range and some of them infect common bean and soy, which are of economic relevance. SBMV is the type species from this genus, has isometric particles (28$30 \mathrm{~nm}$ ) and contains genomic RNA of 4.0-4.5 $\mathrm{Kb}$ with positive polarity and a capsidal protein with a molecular mass of 29-30 kDa. The SBMV genome consists of four Open Reading Frames (ORFs) with sequence overlaps among them. ORF 1 encodes a movement protein with $17 \mathrm{kDa}$ [9]. 


\section{Materials and Methods}

\section{Virus Purification and RNA Extraction}

SBMV was purified from infected leaves of Phaseolus vulgaris following the method of [10]. Viral RNA was extracted using the RNeasy Plant Mini Kit (Qiagen) following the manufacturer's instructions.

\section{Primer Design, cDNA Synthesis and PCR Amplification of the ORF1}

Based on the sequence deposited with the GenBank database under Accession No. DQ875594.2, primers were designed as shown below to amplify the ORF1 from genomic RNA of an isolate of SBMV. BamHI and Hind III restriction sites were incorporated into the forward and reverse primers, respectively.

Forward primer: 5' - CCGGATCCATGAGCTATCGT - 3' (BamHI restriction site highlighted).

Reverse primer: 5' - AAGCTTCCGCGCAGATAA - 3' HindIII (XhoI restriction site highlighted).

First strand cDNA was synthesized using Superscript II Reverse Transcriptase (Invitrogen), and used as a template for the Polymerase Chain Reaction(PCR) for amplification of ORF 1 performed in $100 \mu \mathrm{l}$ mixture containing $50 \mathrm{ng}$ of genomic RNA, $1 \mu \mathrm{L}$ $(10 \mu \mathrm{M})$ of each primer, $2 \mu \mathrm{l}(10 \mathrm{mM})$ dNTPs, $10 \mu \mathrm{l}$ of PCR buffer (100 mM Tris- $\mathrm{HCl} \mathrm{pH} \mathrm{8.8,} 500 \mathrm{mM} \mathrm{KCl,} \mathrm{0.8 \%} 25 \mathrm{mM} \mathrm{MgCl} 2$ ), and $2.5 \mathrm{U}$ of native Taq DNA polymerase enzyme (MBI Fermentas). The amplification was carried out using the following reaction cycles: initial denaturation at $95^{\circ} \mathrm{C}$ for $10 \mathrm{~min}$ followed by 30 consecutive cycles of denaturation at $95^{\circ} \mathrm{C}$ for $30 \mathrm{~s}$, annealing for $1 \mathrm{~min}$ at $55^{\circ} \mathrm{C}$, extension at $72^{\circ} \mathrm{C}$ for $1 \mathrm{~min} 30 \mathrm{~s}$, then final extension at $72^{\circ} \mathrm{C}$ for $10 \mathrm{~min}$. Electrophoresis on a 1\% agarose was used to confirm the specific PCR product obtained and it was purified using PCR gel purification kit (Qiagen).

\section{Cloning in pGEM-T Easy Vector}

The resulting PCR product and pGEM-T Easy vector were ligated at $4{ }^{\circ} \mathrm{C}$ overnight using T4 DNA ligase to yield the pGEM-TMP construct that was transformed into Escherichia coli DH5 $\alpha$ cells. To confirm successful cloning, blue white screening colony and PCR was performed. One clone was used for plasmid extraction and the recombinant vector was sequenced by the automatic ABI 377 DNA Sequencer.

\section{Subcloning in pET28a Vector and pMALc2x}

Recombinant pGEM-T-MP vector was digested with BamHI and HindIII restriction enzymes and a 500bp insert (ORF) was purified from agarose $1 \%$ gel by using gel extraction and purification kit (Qiagen). This product was cloned in pET28a vector (Novagen) and pMALc2x (New England Biolabs) yielding pET28a-MP and pMALMP respectively. Positive clones were first selected by PCR and reconfirmed by restriction digestion. Using pMALc2xsystemthe predicted molecular weight of recombinant MP isapproximately 60 kDA, $42.5 \mathrm{kDa}$ of Maltose Binding Protein (MBP) + $17 \mathrm{kDa}$ of MP and using pET28a is approximately $20 \mathrm{kDa}, 17 \mathrm{kDa}$ of MP + His tag followed by the polylinker sequence.

\section{Expression of Recombinant Protein in E. coli using the pMALc2x Vector}

For the expression of the MP protein tagged with MBP, BL21 E.coli cells were transformed with the pMAL-MP construct and incubated in LB broth (with $0.2 \%$ glucose and $100 \mu \mathrm{g} / \mathrm{ml}$ ampicillin for selection). The medium was inoculated with an overnight culture (1:100 dilution) and the culture was incubated under constant agitation at $25^{\circ} \mathrm{C}$ until an $0 D 600 \otimes 0.5$ was reached. Subsequently, $0.3 \mathrm{mM}$ IPTG was added and the culture was further incubated either at $37^{\circ} \mathrm{C}$ or at $25^{\circ} \mathrm{C}$ for 6 hours.

\section{Purification of the MP-MBP Recombinant Protein}

Cells were harvested by centrifugation at $6,000 \mathrm{xg}$, at $4^{\circ} \mathrm{C}$ for $20 \mathrm{~min}$ and lysed in a buffer containing $20 \mathrm{mM}$ Tris- $\mathrm{HCl} \mathrm{pH} \mathrm{7.4,}$ $200 \mathrm{mM} \mathrm{NaCl}, 1 \mathrm{mM}$ EDTA (including protease inhibitors: $100 \mu \mathrm{g} /$ $\mathrm{ml}$ PMSF, $0.5 \mu \mathrm{g} / \mathrm{ml}$ leupeptin, $0.5 \mu \mathrm{g} / \mathrm{ml}$ aprotinin and $1 \mu \mathrm{g} / \mathrm{ml}$ pepstatin) by sonication for $2 \mathrm{~min}$ on ice. The crude extract was isolated by centrifugation of the samples at $15,000 \mathrm{xg}$ at $4^{\circ} \mathrm{C}$ for 1 hour and was applied on to a column containing an amylose resin pre-equilibrated with the lysis buffer. The recombinant protein was eluted after the addition of the lysis buffer with $10 \mathrm{mM}$ maltose and a final step of gel filtration using a Superdex G75 10/300 GL column, was performed. The presence of the MP through all the steps of expression and purification steps was monitored by SDSPAGE gels.

\section{Preparation of Polyclonal Antibodies against the Recombinant MP}

Antibodies against the recombinant MP were raised in a male New Zealand white rabbit which was injected subcutaneously with $1 \mathrm{mg}$ of the purified recombinant MP-MBP protein in $5 \mathrm{mM}$ Tris- $\mathrm{HCl}$ pH 7.5; $100 \mathrm{mM} \mathrm{NaCl}$. Four booster injections were administered with $1 \mathrm{mg}$ of recombinant protein each at an interval of one week. One week after the final injection, $50 \mathrm{ml}$ of blood was collected and maintained overnight at room temperature. The crude antiserum was collected by centrifugation ( $4200 \mathrm{x}$ g for $5 \mathrm{~min}$ ) and the globulin fraction was isolated by three rounds of selective precipitation with ammonium sulfate ( $40 \%$ saturation). After the final round of precipitation, the proteins were dissolved in $20 \mathrm{ml}$ of $5 \mathrm{mM}$ Tris- $\mathrm{HCl}$ pH 7.5, $200 \mathrm{mM} \mathrm{NaCl}$. The titer and the specificity of the antiserum were checked by western blot and dot blot.

\section{Expression of Recombinant Protein in $E$. coli using the pET28a Vector}

For expression of the His-tagged MP, BL21 E.coli cells were transformed with the pET28a-MP construct and incubated in LB broth $(100 \mu \mathrm{g} / \mathrm{ml}$ kanamicin for selection). The medium was inoculated with an overnight culture (1:100 dilution) and the 
culture was incubated under constant agitation at $30^{\circ} \mathrm{C}$ until an $\mathrm{OD}_{600} \varangle 0.5$ was reached. Subsequently, $0.3 \mathrm{mM}$ IPTG was added and the culture was further incubated either at $30^{\circ} \mathrm{C}$ or at $18^{\circ} \mathrm{C}$ for 8 hours.

\section{Purification of His-Tagged MP}

Expression of MP using pET28a in E. coli was fraught with difficulties, including poor expression, degradation, and sequestration as insoluble protein in inclusion bodies; therefore it was purified under denaturing conditions and subsequently refolded. After sonication, the insoluble fraction from 1 liter of culture was washed 5 times with a wash solution $(20 \mathrm{mM}$ Tris- $\mathrm{HCl} \mathrm{pH}$ 8.0, $50 \mathrm{mM} \mathrm{NaCl}$, deoxycholate 2\%, $1 \mathrm{mM}$ DTT) and resuspended in $20 \mathrm{ml}$ denaturing buffer ( $100 \mathrm{mM} \mathrm{NaH} 2 \mathrm{PO} 4 \mathrm{pH} 8.0$, $8 \mathrm{M}$ urea). Cell debris was removed by centrifugation at $15,000 \mathrm{x}$ $\mathrm{g}$ for $20 \mathrm{~min}$. The recombinant MP was purified under denaturing conditions using Nickel Sepharose (GE). Initially the column was loaded with $20 \mathrm{ml}$ of the binding buffer (100 mM NaH2PO4 pH 8.0, $8 \mathrm{M}$ urea) and washed with 6 column volumes of the wash buffer (100 mM NaH2PO4 pH 6.3, $8 \mathrm{M}$ urea). The column bound protein was subsequently eluted with $10 \mathrm{ml}$ of elution buffer $(100 \mathrm{mM}$ $\mathrm{NaH} 2 \mathrm{PO} 4, \mathrm{pH}$ 4.0, $8 \mathrm{M}$ urea) and the concentration was determined, adjusted to $1 \mathrm{mg} / \mathrm{ml}$ and checked by SDS-PAGE gels. The purified protein was used in western blot, dot blot and refolding assays.

\section{Refolding of MP}

His-tagged MP was refolded following a simple dilution protocol in Tris- $\mathrm{HCl}$ pH 7.5 buffer which additionally contained 200 mM NaCl, 1 mM DTT , 1 M 3-(1-Pyridinio)-1-propanesulfonate, at $4 \mathrm{oC}$, wherein the $8 \mathrm{M}$ urea solution containing the recombinant MP (1 mg/ml) was diluted to a concentration $10 \mu \mathrm{g} / \mathrm{ml}$. The sample containing the diluted purified protein was concentrated by centrifugation inan AMICON (3.000 Da) micro-concentrator by centrifugation at $4,000 \mathrm{xg}$ at $10^{\circ} \mathrm{C}$.

\section{Circular Dichroism Spectroscopy of Refolded MP}

Far UV-CD spectra in the range 190-260 nm were obtained with quartz cells with a path lengths of $0.5 \mathrm{~mm}$ and a scan rate $50 \mathrm{~nm} / \mathrm{min}$ at $25 \mathrm{oC}$ with a response time of 1.0 second, spectral bandwidth of $1.0 \mathrm{~nm}$ and a spectral resolution of $0.1 \mathrm{~nm}$ by utilizing a Jasco J-710 Spectropolarimeter (Jasco, Tokyo, Japan). For each spectrum, 10 accumulations were performed. Secondary structure percentages for each tested condition were calculated with CONTINLL software of CDPro package, using the reference set of proteins SMP56 [11].

\section{Western Blot Evaluation}

To determine the specificity of polyclonal antiserum, MP Histagged that has no MBP $(10 \mu \mathrm{g})$ was used in immunoassays to make sure that the polyclonal antibody has affinity for the sequence encoded by ORF1 avoiding reaction with MBP fusion protein. MP His-tagged, and two negative controls, the recombinant C-terminal portion of RNA polymerase of SBMV $(500 \mu \mathrm{g})$ and BSA (500 $\mu \mathrm{g})$, were applied on $15 \%$ SDS-PAGE gels, and then electroblotted onto a $0.22 \mathrm{~mm}$ pore size nitrocellulose membrane at a constant current of $80 \mathrm{~mA}$ for $1 \mathrm{~h}$. An identical gel was run and stained with Comassie brilliant BlueR-250. After blocking in TBS (20 mM Tris-HCl pH 7.4, $150 \mathrm{mM} \mathrm{NaCl}$ ) with $5 \%(\mathrm{w} / \mathrm{v}$ ) skimmed milk, the membrane was incubated with polyclonal antibodies against MP-MBP (1:2000 diluted in TBS) at $25^{\circ} \mathrm{C}$ for $2 \mathrm{~h}$. After washing three times, goat-antirabbit IgG conjugated with alkaline phosphatase (Sigma) was added and incubated for $1 \mathrm{~h}$ at room temperature. The immunoreactive bands were subsequently visualized by using 5-Bromo-4-Chloro3-Indolylphosphate (BCIP) and Nitro Blue Tetrazolium (NBT) as a substrate.

\section{Western Blot Analysis of Proteins Extracted from Infected Bean Leaves}

Following inoculation of bean leaves with the purified virus for different time intervals, the bean leaves were harvested, and 1 gram was homogenized by grinding in $1 \mathrm{ml}$ of $50 \mathrm{mM}$ Tris- $\mathrm{HCl}, \mathrm{pH}$ 7.5, 9 M urea, 10\% SDS, 5\% 2-mercaptoethanol. The sample was boiled for $5 \mathrm{~min}$, centrifuged at $10,000 \mathrm{x}$ g for $10 \mathrm{~min}$ and $20 \mu \mathrm{L}$ of the supernatant was applied in $12 \%$ SDS-PAGE gels. The proteins were electro-blotted onto a nitrocellulose membrane and submitted for Western blot assays as described above.

\section{Dot Blot}

The purified recombinant movement protein was also analyzed by dot blot in two different experiments. First, $20 \mathrm{ng}$ of the Histagged MP was spotted onto strips of a nitrocellulose membrane and was used to determine the efficiency of the obtained antiserum that was diluted 2000 fold. The second experiment consisted of a serial dilution of the recombinant protein in PBS that was spotted on the membrane at $2 \mu \mathrm{l} /$ spot and incubated with polyclonal antibodies against MP-MBP (1:2000 diluted in TBS) at $25^{\circ} \mathrm{C}$ for 1 $\mathrm{h}$. The samples were washed and visualized following the Western blot analysis protocol. This experiment was repeated twice using both denatured and refolded proteins.

\section{Prediction of Linear Epitopes}

Putative linear epitopes of MP of SBMV were predicted using the program BepiPred [12]. The prediction score is based on hydrophilicity and secondary structure prediction from a single sequence.

\section{Results and Discussions}

\section{Virus Purification, RNA extraction and Cloning of ORF1 from SBMV}

From infected bean leaves it was possible to purify viral particles with high purity (Figure 1), serving as a source of RNA for cDNA synthesis. In this study, ORF1 of SBMV was cloned into the expression vectors pMALc2x and pET28a. 


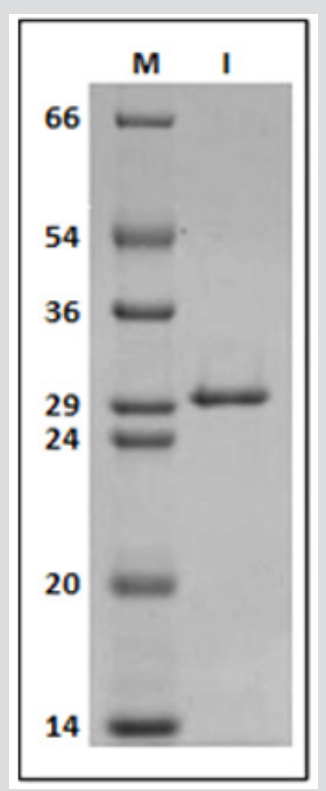

Figure 1: 12\% SDS-PAGE gel labeled in $\mathrm{kDa}$; $(\mathrm{M})$ molecular marker, (1) Purified Southern bean mosaic virus.

\section{Expression and Purification of Recombinant MP-MBP}

Using pMALc2x it was possible to purify a recombinant movement protein of approximately $60 \mathrm{kDa}$ (Figure 2). This expression vector was chosen not only based on solubility and stability of MBP-MP, but also because MBP might enhance immune responses to vaccine fusion proteins $[13,14]$ facilitating the production of antibodies as it has been demonstrated in mice and rabbits eliciting a strong IgG antibody response against both the dengue virus [15,16] and Plasmodium falciparum [17].

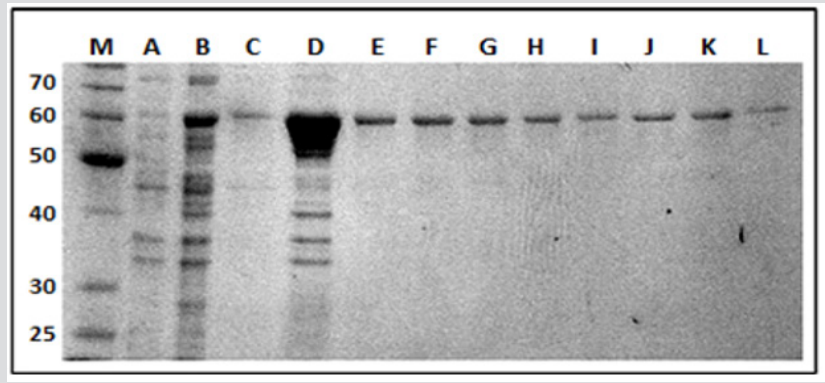

Figure 2: $12 \%$ SDS-PAGE gel of the purified MP-MBP labeled in $\mathrm{kDa}$. Lane (M), molecular-weight markers; (A) non-induced E. coli sample; (B) E. coli sample 1 hour after IPTG induction;(C) following the wash step. Lanes D, E, F, G, H, I, J, K and L, represent elution fractions of MP-MBP.

SDS-PAGE analysis of the recombinant clone containing recombinant pMALc2x-MP indicated high levels of production of soluble recombinant proteins after induction with IPTG, permitting purification in the native state by conventional amylose resin chromatography. A final step of gel filtration utilizing a Superdex G75 10/300 (GE-Healthcare life sciences) column was performed. The protein was concentrated to $1 \mathrm{mg} / \mathrm{mL}$, the purity was checked by SDS-PAGE gels (Figure 2) and was used for the production of polyclonal antibodies in rabbits.

\section{Expression and Purification of Recombinant Protein in E. coli using pET28a Vector}

This system was successful in expressing the N-terminal Histagged MP that was subsequently purified under denaturing conditions.

\section{Circular Dichroism Spectroscopy of Refolded MP}

The refolding of MP was analyzed based on the percentages of secondary structure calculated by the CONTINLL software of the CDPro package, using the reference set of proteins SMP56 [11] and indicate a structural content of $25 \% \alpha$-helix, $39 \% \beta$-sheet, $18 \%$ turns and $18 \%$ random coil (Figure 3). Using the purified recombinant MP-MBP as the antigen, its polyclonal antiserum was prepared successfully through the procedure described in the Materials and Methods. To avoid reactions among the antibodies and the Maltose Binding Fusion Protein (MBP) in immunoblotting assays, all experiments were performed using MP His-tagged, ensuring that during experiment the antibodies recognize specifically the amino acid sequence encoded by ORF1 of SBMV.

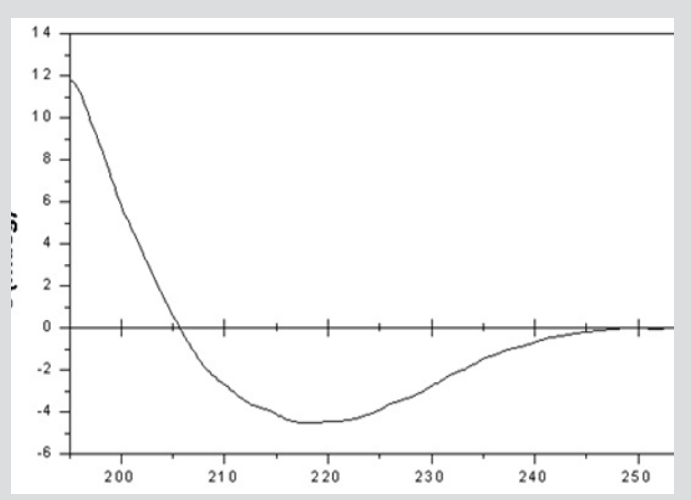

Figure 3: Circular dichroism spectrum of a sample of the refolded MP. The protein conformation consists of $25 \%$ a-helix, $39 \% \beta$-sheet, $18 \%$ turns and $18 \%$ random coil.

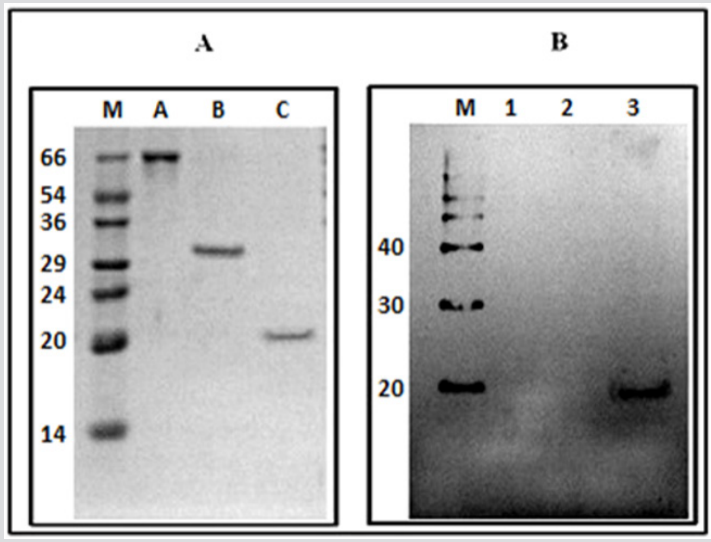

Figure 4: Panel (A) 12\% SDS-PAGE gel (numbers indicate $\mathrm{kDa}$ ); (M) molecular-weight markers; (A) BSA; (B) C-terminal domain of SBMV polymerase; (3) His-tagged SMBV MP. Panel (B) Western blot using the anti-histidine monoclonal antibody. (M), molecular marker, Magic Mark XP (Invitrogen) (1) BSA, (2) C-terminal portion of the polymerase of SBMV; (3) MP His-tagged of SBMV. 


\section{Western Blot}

Western blot showed the specificity of the antibodies reacting positively with MP His-tagged (20 kDa), but not with BSA and recombinant C-terminal portion of SBMV polymerase, even 5 times more concentrated than the MP (Figure 4).

\section{Dot Blot}

Twenty ng of the refolded His-tagged MP spotted onto strips of nitrocellulose membrane was used to determine the efficiency of the obtained antibody and we found that the antiserum at different dilutions (1:1.000; $1: 2.000 ; 1: 4.000 ; 1: 8.000 ; 1: 16.000$; $1: 32.000$ ) reacted with the recombinant protein. The same assay was performed using denatured and refolded MP and no difference was found between them (Figure 5). The minimal dilution of antiserum able to react with $20 \mathrm{ng}$ of MP was 1:16000. Analyzing serial dilutions of recombinant MP His-tagged, it was possible to conclude that at least $1.8 \mathrm{ng}$ of protein is detectable using the antiserum diluted 1:2000 (Figure 6).

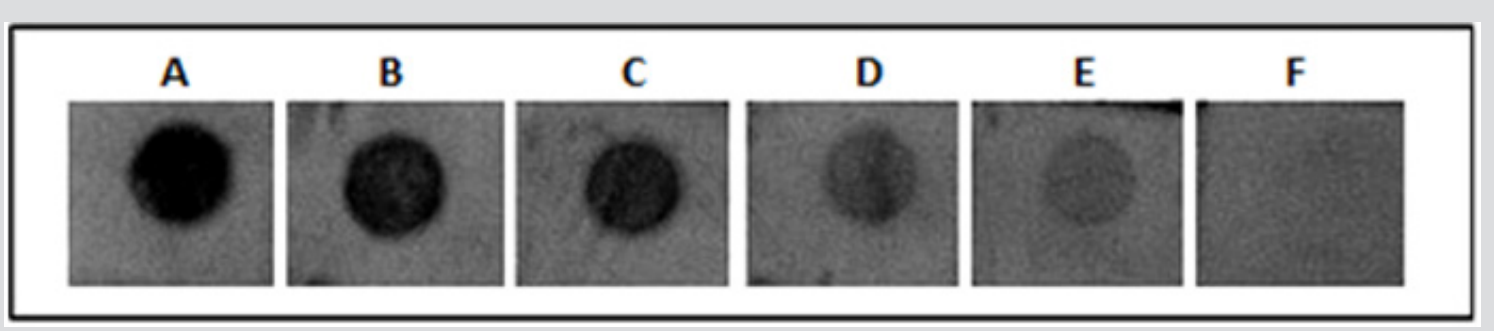

Figure 5: Titration assay by dot blot using polyclonal antibody against MP of SBMV. Each dot contains 20 ng of refolded MP His-tagged. A to F represent the following dilutions of antiserum: 1:1.000; 1:2.000; 1:4.000; 1:8.000; 1:16.000; 1:32.000.

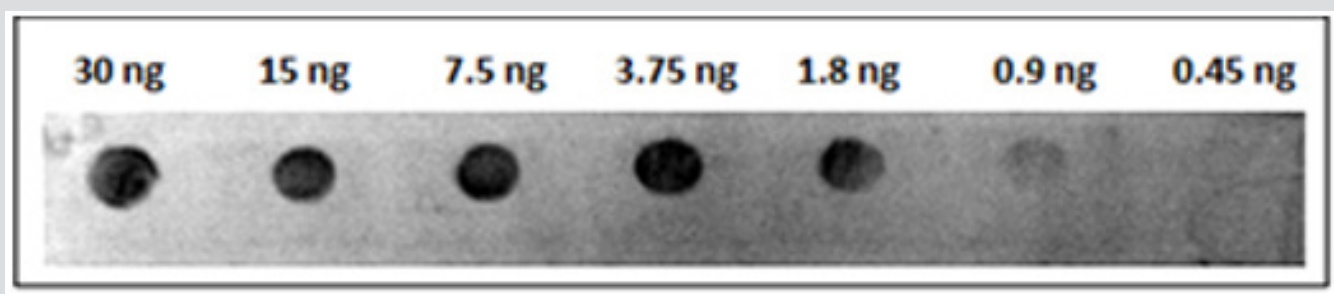

Figure 6: Titration assay by dot blot using polyclonal antibody against MP of SBMV. Different concentration of MP of SBMV were detectable using the antiserum diluted 1:2000.

MP of SBMV was not detected in experiments using proteins from the crude extracts of bean leaves indicating that the sample applied in membrane has MP concentration lower than $1.8 \mathrm{ng}$ (90 ng/gram of sample of infected leaf) or that MP was degraded during the viral infection cycle.

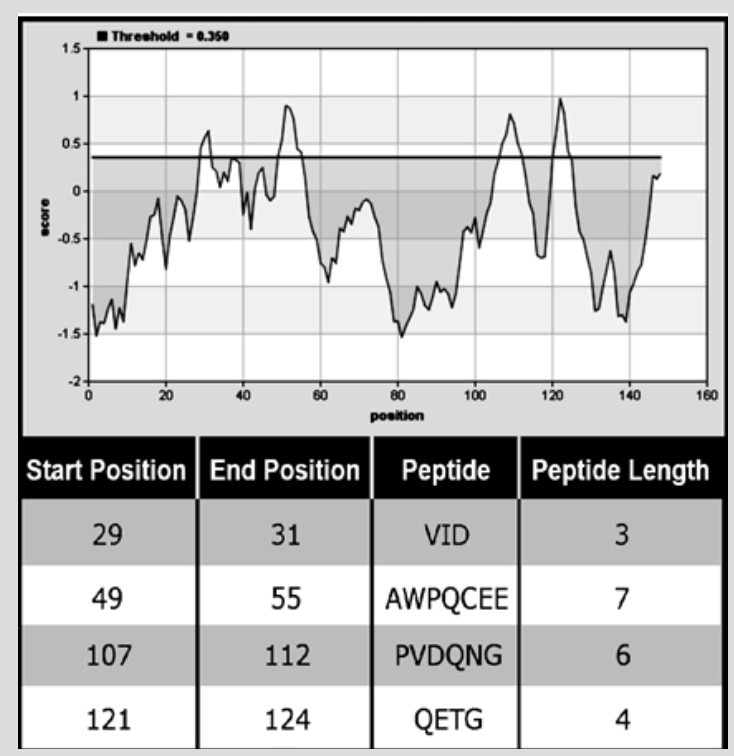

Figure 7: Graphical result of Bepipred Linear Epitope Prediction tool. The Positive scores for linear epitopes and their predicted epitopes along with each respective sequence are showed in the table associated with the graphic. 


\section{Prediction of Linear Epitopes}

The Bepipred Linear Epitope Prediction tool was used in order to explain the antibodies recognition of denaturing and native form of MP guided by algorithms that predict immunogenic epitopes. Four main linear epitopes were predicted (Figure 7). Antibodies may recognize epitopes made up of contiguous (conformational epitope) or non-contiguous (linear epitope) amino acids and according to these results, it is suggested that the MP has surfaceexposed linear epitopes in native state. The advantage of using an antiserum that recognizes both native and denatured proteins is the possibility to use additives that can change the folding of the target protein without disturbing its recognition.

\section{Conclusion}

The movement protein was cloned and over expressed in E. coli and was subsequently used as an antigen to produce antibodies against the recombinant protein with high specificity. Since the prepared polyclonal antibody is able to react specifically with MP protein of SBMV under both denaturing and native conditions, it may serve as a tool to identify its sub-cellular localization and can help to understand its role in virus replication. Based on immunoblotting assays of infected bean leaves we conclude that the MP concentration per gram of sample of infected leaves is less than $90 \mathrm{ng}$ or that the MP is degraded during the viral infection cycle.

\section{Acknowledgement}

This work was supported by grants from Conselho Nacional de Desenvolvimento Ciêntifico e Tecnológico (CNPq/Brazil) Grant 307338/2014-2 and FAPESP (Fundação de Amparo à Pesquisa do Estado de São Paulo) Grant numbers 2018/10736-8; 2018/079773; 2015/13765-0 and 2015/18868-2.

\section{References}

1. Lucas WJ, Gilbertson RL (1994) Plasmodesmata in relation to viral movement within leaf tissues. Annual Review of Phytopathology 32(1): 387-415.

2. Carrington JC, Kasschau KD, Mahajan SK, Schaad MC (1996) Cell-to-cell and long-distance transport of viruses in plants. Plant Cell 8(10): 16691681.

3. Robert L Gilbertson, William J Lucas (1996) How do viruses traffic on the 'vascular highway'? Trends in Plant Science 1(8): 250-251.

\section{ISSN: 2574-1241}

\section{DOI: 10.26717/BJSTR.2019.15.002678}

Raghuvir K A, Ricardo M. Biomed J Sci \& Tech Res

This work is licensed under Creative

Commons Attribution 4.0 License

Submission Link: https://biomedres.us/submit-manuscript.php
4. Deom CM, Lapidot M, Beachy RN (1992) Plant virus movement proteins. Cell 69(2): 221-224.

5. Chowdhury SR, Savithri HS (2011) Interaction of Sesbania mosaic virus movement protein with the coat protein-implications for viral spread. FEBS Journal 278(2): 257-272.

6. Scholthof HB (2005) Plant virus transport: Motions of functional equivalence. Trends in Plant Science 10(8): 376-382.

7. Lucas WJ (2006) Plant viral movement proteins: Agents for cell-to-cell trafficking of viral genomes. Virology 344(1): 169-184.

8. Hull R (2002) Matthews' Plant Virology, (4 ${ }^{\text {th }}$ edn.), Gulf Professional Publishing, New York, pp. 1001.

9. Sivakumaran K, Fowler BC, Hacker DL (1998) Identification of viral genes required for cell-to-cell movement of southern bean mosaic virus. Virology 252: 376-386.

10. Moreira AE, Gaspar JO, Camargo LE, Kuniyuki H (2004) Characterization of the gene of the capsid protein of Grapevine virus A in vines affected by the Kober wood groove in the State of São Paulo. Fitopatol bras 29: 205-208.

11. Sreerama N, Woody RW (2000) Estimation of protein secondary structure from circular dichroism spectra: comparison of CONTIN, SELCON, and CDSSTR methods with an expanded reference set. Anal Biochem 287(2): 252-260.

12. Larsen JE, Lund O, Nielsen M (2006) Improved method for predicting linear b-cell epitopes. Immunome Research 2(1): 1.

13. Fox JD, Kapust RB, Waugh DS (2001) Single amino acid substitutions on the surface of Escherichia coli maltose-binding protein can have a profound impact on the solubility of fusion proteins. Protein Sci 10: 622630.

14. Fernandez S, Palmer DR, Simmons M, Sun P, Bisbing J (2007) Potential role for Toll-like receptor 4 in mediating Escherichia coli maltosebinding protein activation of dendritic cells. Infection and Immunity, 75(3): 1359-1363.

15. Simmons M, Murphy GS, Hayes CG (2001) Short report: Antibody responses of mice immunized with a tetravalent dengue recombinant protein subunit vaccine. Am J Trop Med Hyg 65(2): 159-161.

16. Simmons M, Murphy GS, Kochel T, Raviprakash K, Hayes CG (2001) Characterization of antibody responses to combinations of a dengue-2 DNA and dengue-2 recombinant subunit vaccine. Am J Trop Med Hyg 65(5): 420-426.

17. Kushwaha A, Rao PP, Suresh RP, Chauhan VS (2001) Immunogenicity of recombinant fragments of Plasmodium falciparum acidic basic repeat antigen produced in Escherichia coli. Parasite Immunology 23(8): 435444 .

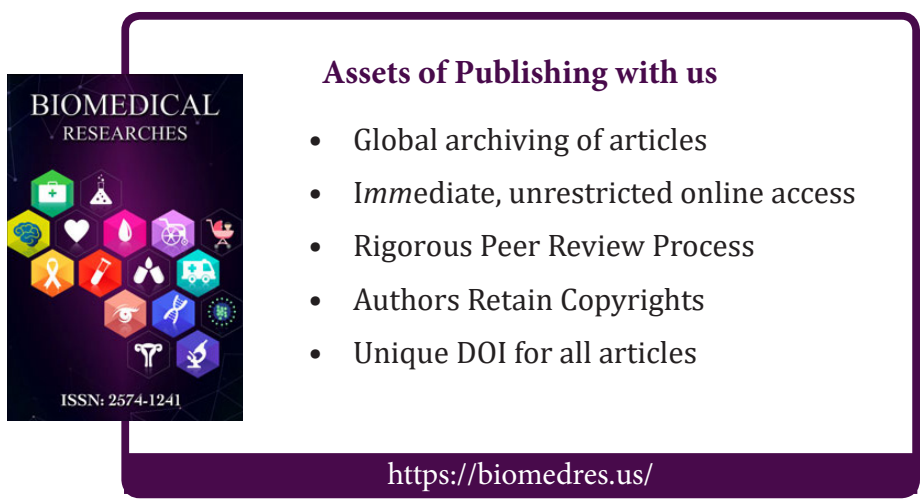

Copyright@ Raghuvir Krishnaswamy A, Ricardo M| Biomed J Sci \& Tech Res| BJSTR. MS.ID.002678. 